\title{
Women on German management boards
}

\section{How ownership structure affects management board diversity}
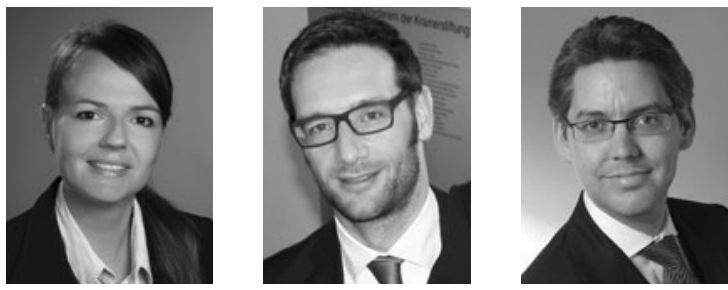

\section{Jana Oehmichen • Marc Steffen Rapp • Michael Wolff}

\begin{abstract}
In this paper we want to investigate the impact of company owners on the low percentage of women on management boards and whether they are attempting to increase this percentage. After analysing whether ownership concentration influences the number of women on management boards we distinguish between different types of owners. We find that ownership concentration has no effect on the presence of women on German management boards, we show however that institutional and individual owners have a significantly positive effect. Classifying institutional owners into national and foreign owners illustrates that foreign investors are the primary driver of the positive effect within the class of institutional owners; the presence of national investors that are strongly influenced by the national banking system does not show any effect. Our analyses are based on 15,976 management board member positions from 2000 to 2007 in approximately 600 German-listed companies.
\end{abstract}

Keywords: Management board $\cdot$ Gender $\cdot$ Women $\cdot$ Corporate governance

JEL Classification: $\mathrm{G} 30 \cdot \mathrm{G} 34 \cdot \mathrm{C} 23$

C The Author(s) 2011. This article is published with open access at Springerlink.com

Dr. J. Oehmichen $(\bowtie) \cdot$ Prof. Dr. M. Wolff

Chair of Management and Control, Georg-August-University Göttingen,

Platz der Göttinger Sieben 3, 37073 Göttingen, Germany

e-mail: jana.oehmichen@wiwi.uni-goettingen.de

Prof. Dr. M. Wolff

e-mail: michael.wolff@wiwi.uni-goettingen.de

Prof. Dr. M. S. Rapp

Institute of Management Accounting, Philipps-University Marburg,

Am Plan 1, 35032 Marburg, Germany

e-mail:msr@m-s-rapp.de 


\section{Introduction}

Since the financial crisis began in 2008, in many countries there has been greater attention to the diversity in companies' boardrooms, even though only a modest increase in the percentage of women in these positions can be observed worldwide. After analyzing 4,200 companies around the world, GovernanceMetrics International found that the percentage of female board members increased marginally between 2009 and 2011, from 9.2 to $9.8 \%$ (GovernanceMetrics International (GMI) 2011).

The public discussion in Germany has also noted for some time that there are too few women in German top management positions. German policy has recognised this issue at least since 2001 when the German Federal Ministry for Family Affairs, Senior Citizens, Women and Youth enacted the agreement on the promotion of gender equality in the German private sector. However, the impact of this agreement has not been satisfactory (Holst and Wiemer 2010). Therefore, further possible solutions remain a topic in the public discussion. The German Corporate Governance Codex requires the consideration of an adequate level of diversity when appointing management and supervisory board members (Weber-Rey 2009). In addition, the option of a hard quota law following the example of Norway is frequently discussed. At a company level, the German Telekom was the first DAX company to introduce an internal quota law in 2010 (Holst and Wiemer 2010). Today, $20 \%$ of the companies listed in the DAX are committed to an internal quota regulation. ${ }^{1}$

At the same time, researchers have focused more and more on female board representation. They have found evidence that while it is important for companies to have women on management teams, they are underrepresented - especially among top managers and board members (Adams and Ferreira 2009; Daily et al. 1999; Hillman et al. 2007). The identification of the factors supporting the presence of women on boards is essential (Hillman et al. 2007). Naturally, one of the most influential institutions involved in decisions on the corporate governance structure are the companies' owners. ${ }^{2}$ Drawing on the assumptions of the classical agency theory, they rely on finding an adequate representative of their interests as manager. This search might have interesting effects on the gender diversity among board members.

Among existing investigations of the ownership impact on board diversity the following gaps can be identified: Since different types of owners generally have different interests, a detailed distinction of the impact of different types of owners on the presence of women on the management board is indispensable. While there are some studies that focus on the impact of a specific type of owner - the institutional investors - on board diversity (Carleton et al. 1998; Farrell and Hersch 2005), no holistic examination of different owners exists. This holds first, concerning the type of owner and second, concerning the geographic origin of the owner. We close these gaps by first distinguishing between families, banks and insurance companies, strategic and institutional owners and by second separating domestic and foreign owners. From a German point of view, an additional gap is the general lack of a representative empirical analysis of corporate governance drivers for the presence of women on management boards. We close this gap by analysing 15,976 management board member positions including approximately 600 German-listed companies from 2000 to 2007.

In this paper, we focus on the following three research questions: First, does ownership concentration affect the presence of women among management board members? Own- 
ers with large shares have a stronger influence on strategic decisions in the companies they own. Large shareholders are more involved in the process of appointing management board members and therefore prevent the reproduction of the same male elite in German top management positions. Second, do specific types of owners focus more on management board diversity than others? For example, institutional investors such as investment funds and private equity investors have a higher impact on strategic decisions and changes in corporate governance patterns (Thomsen and Pedersen 2000). Third, do differences exist between the impacts of foreign and national institutional investors on the representation of women in management boards? While German institutional owners are mostly subsidiaries of German banks or insurance companies (Böhler et al. 2010; Edwards and Nibler 2000), foreign institutional investors can be considered as the classical, active owners and specialised investors whose success is measured by the success of their investments (Thomsen and Pedersen 2000). They are even more reliant on trustworthy corporate governance structures, since they are generally exposed to higher monitoring costs (Leuz et al. 2009). Hence, we expect mainly foreign institutional investors to positively affect the presence of female managers.

Our study contributes to literature in three dimensions: understanding of the influence of ownership structure on strategic decisions, drivers of board diversity and the German corporate governance system. The term diversity can thereby cover a multitude of dimensions. Demographic diversity attributes such as race, age, gender can be considered, as well as educational and functional background (McPherson and Smith-Lovin 1987; Pelled 1996; Simons et al. 1999). However, researchers have identified gender as the strongest driver for stereotypes and categorisation behaviour (Hollingshead and Fraidin 2003). For this reseaon, we pay special attention to this dimension and use the terms diversity and gender diversity interchangeably. We extend the existing literature on the influence of ownership structure on company performance and strategic decisions made in companies (Anderson and Reeb 2003a; Andres 2008; Barclay et al. 2009; Kronborg and Thomsen 2009; Renneboog 2000) by the dimension of management board diversity. We show that the influence of owners on board diversity does not depend on their concentration, but rather on the specific type of owner. We thereby extend the classical agency theory based research on the owners as principals and the managers as agents (Fama and Jensen 1983) by an additional dimension for conflicts of interest: while managers want to demographically "reproduce" themselves, owners are interested in implementing state-ofthe-art corporate governance structures. Concerning drivers of board diversity, we provide a unique investigation of ownership microstructures, such as the impact of international institutional owners on the acceptance of women on management boards. Thereby, we clearly extend the results of Farrell and Hersch (2005) and Carleton et al. (1998), who do not distinguish between national and international owners. We also enhance the research community's understanding of the German corporate governance system with our unique data set. Based on 5,203 company years and a consideration of 15,976 management board member positions, our study is the first representative empirical analysis of women on German management boards and the variables associated with their presence. ${ }^{3}$

The paper is structured as follows. Part two gives an overview of the existing literature. Part three outlines the theoretical framework and introduces the hypotheses. Our sample and the variables used are explained in part four. In part five, we present our empirical results and the robustness checks. Finally, part six concludes our study and discusses the results. 


\section{Literature review}

Academic research of women on corporate boards can generally be classified into two groups: the first group of papers analyses the impact of top female managers on companies' performance and decision quality while the second group focuses on drivers and detractors of women on corporate boards. To give an overview of the existing literature, we summarise the current status of research results in the first group and continue with a detailed description of the placement of our paper within the current results of the second group.

Research on the impact of female managers on company performance and decision quality is generally driven by two arguments. The first argument is that women represent additional human capital for top management positions that is as yet unused (Westphal and Milton 2000). By not considering one half of society for its management positions, companies generally lose a large pool of potential intelligence (Brammer et al. 2009; Oehmichen 2010). The discriminated minority therefore becomes demotivated (Brammer et al. 2009) and unlikely to invest in its human capital (Becker 1985; Coate and Loury 1993). The second argument is that diversity enhances divergent thinking and thereby improves the quality of decisions made by the management board (Aretz and Hansen 2003; Hillman et al. 2007; Lederle 2007). An increased share of women in management can increase the pool of points of view, knowledge, skills and experiences. Furthermore, via an extended intellectual spectrum, the comprehensive range of experience and creativity can be strengthened (Arfken et al. 2004). Additionally, the acceptance of the company in employee and product markets can be improved by increased legitimacy through board diversity (Daily et al. 1999; Hillman et al. 2007). However, these expected advantages of diversity are accompanied by potential costs, such as insufficient communication (Ferreira 2010; Kilduff et al. 2000) or the decrease in psychological attachment to the company (Tsui et al. 1992). The aggregate effect of diversity depends on the company's environment (Goodstein et al. 1994). Empirical studies on the impact of female board members on company performance yield ambiguous results. Cater et al. (2003) found a positive (Carter et al. 2003), whereas Adams and Ferreira (2009) found a negative effect (Adams and Ferreira 2009) on performance.

The existing literature on drivers and detractors of female careers and especially of women on corporate boards covers country-specific institutional (Straub 2007; Terjesen and Singh 2008) and company-specific organisational aspects (Fryxell and Lerner 2009; Harrigan 1981; Hillman et al. 2007). Research on the country level shows that the presence of women on boards strongly depends on countries' social, political, and economic patterns (Terjesen and Singh 2008). Countries that adopt the cultural norm of stay-at-home mothers, in other words women delaying their careers in order to keep their husband's options open or to educate their children, have lower percentages of women in management positions (Tharenou 2008).The possibility to deduct housekeeping expenses from income tax on the other hand is a significant country-wide incentive for women to occupy management positions (Henrekson and Stenkula 2009).

Among company-specific organisational drivers, we distinguish between industry affiliation, company characteristics and corporate governance characteristics. Two kinds of industry effects are possible: the availability of more female employees in specific indus- 
tries (Hillman et al. 2007), and the social pressure of more female customers in some industries (Fryxell and Lerner 2009). Harrigan (1981), one of the first academic authors to address drivers of female directors, using an US-American sample, found certain industries such as pharmaceuticals, cosmetics and chemical processing to positively affect the likelihood of women being members of the board (Harrigan 1981). Companies affiliated with an industry with more female customers are expected to have a higher percentage of female managers in order to provide higher credibility in the product market. Having no female manager can have a destructive effect on the company's reputation among its female customers. Fryxell and Lerner (2009) identified in their US-American sample food, drug and cosmetic product groups as companies with a higher rate of acceptance of female board members because they recognise that these are industries with augmented numbers of female customers (Fryxell and Lerner 2009). Though industry affiliation is not part of our hypotheses, we control for it in our multivariate models (Farrell and Hersch 2005).

Company characteristics that might influence the presence of female managers are organisational details, such as company size, as well as concrete activities the companies undertakes to increase the percentage of women among their managers. Empirical results regarding the effect of company size on the acceptance of women on boards are mixed. Harrigan (1981) detects a negative effect between company size and women board members, whereas the more current publications of Hillman et al. (2007) and Farrell and Hersch (2005) observe a positive effect. This trend however is not surprising; female managers have gradually moved to the fore of public opinion in the last 10 years and the resulting social pressure is most relevant for large companies. Specific programs that companies can engage in to increase the percentage of female managers include the following: the introduction of diversity responsibilities such as a diversity commissioner, the elimination of distorted perceptions of female managerial abilities via trainings and workshops, programs to facilitate the integration of work and family activities, and the reduction of social isolation via mentoring programmes and networking events (Kalev et al. 2006; Krell 2008; Noe 1988; Süß 2008).

Corporate governance structures that might drive or detract female managers from top management positions are the board and ownership structure. Research results concerning the impact of the board structure include the following: In their 2SLS regression analysis, Carter et al. (2003) identified board size as a positive driver for the presence of women on boards. Conversely, the number of inside directors negatively affects the presence of female directors. Their results are based on an empirical analysis of 638 US-American companies for only one cross-section (Carter et al. 2003). Farrell and Hersch (2005) questioned which kind of director a woman is most likely to replace on the board. They discovered that a departing woman increases the likelihood of another woman being added. Furthermore, Farrell and Hersch controlled for board size. Hillman et al. (2007) extended these analyses by investigating whether there is an expected positive effect of an "outside female director link". They show that boards that network with other female board members have a positive impact on the acceptance of female board members.

The impact of owners on the presence of women on boards is mainly covered by Carleton et al. (1998) and Farrell and Hersch (2005). Carleton et al. (1998) investigated the general impact of institutional investors on corporate governance decisions. Within these analyses, they found some significant influence of institutional investors (TIAA-CREF in 
their case) on the gender diversity of boards (Carleton et al. 1998). Farrell and Hersch (2005) came to the same conclusion: they show that the percentage of institutional ownership has a positive impact on the appointment of women as directors (Farrell and Hersch 2005). They also showed that institutional investors seem to generate some outside pressure for more board diversity. Farrell and Hersch included banks and insurance companies in their definition of institutional owners but disregarded other types of owners, which could also influence the appointment of female directors.

This is where we fill the research gap. From an agency theoretical perspective, it is important to consider different dimensions of the major interests of different types of owners and to follow different attitudes concerning the importance of women on boards. Therefore, we extend their findings in three ways. First, in our analyses of the impact of ownership structure on the presence of women on management boards ${ }^{4}$ we further separate the definition of institutional investors into investment funds, private equity funds and venture capitalists on the one hand, and banks and insurance companies on the other hand. Second, we add strategic and individual owners to our models, and third, we distinguish between national and international institutional investors. We thereby close an existing gap, since the current research offers little detailed guidance as to "why some companies do have female representatives on their boards and others do not" (Hillman et al. 2007).

Our research is of (Barth et al. 2005) additional relevance for research on general ownership effects. Many papers investigating the impact of shareholders focus on the effects on a company's performance (Anderson and Reeb 2003a; Himmelberg et al. 1999; Morck et al. 1988) instead of looking for concrete strategic decisions that active owners could influence. Strategic dimensions covered so far include dividend payout (Barclay et al. 2009), corporate diversification (Anderson and Reeb 2003b; Denis et al. 1997), productivity (Barth et al. 2005) or company leverage (Anderson and Reeb 2003b). By analysing shareholders' effects on the acceptance of female managers, we add a further exemplary strategic decision to this area of research.

\section{The impact of the ownership structure on the presence of female managers: hypotheses}

Many researchers have investigated the impact of ownership structure over time. The foundation was laid by Berle and Means (1968), who observed the following effects of the separation of ownership and control, a trend that started in the 19th century. Owners turn from active to passive agents, the spiritual value of ownership is replaced by its monetary value and the owners lose their active influence on their personal wealth (Berle and Means 1968). The resulting conflicts of interests between owners and managers, as well as possible dimensions for owners to reduce their agency costs, find consideration in many academic publications (Fama and Jensen 1983; Jensen 1986, 1993; La Porta et al. 2000; Shleifer and Vishny 1997).

Many studies on the effects of ownership characteristics focus on the influence of ownership structure on a company's performance (Anderson and Reeb 2003a; Edwards and Weichenrieder 2004; Franks and Mayer 2001; Himmelberg et al. 1999). They often presume that owners with larger shares have lower agency costs of monitoring, exert more 
influence over the companies' management and therefore increase their company's value (Edwards and Weichenrieder 2004; Jensen and Meckling 1976).

To examine the impact of owners on questions of board composition, we first need to understand the preferences of management board members. These (primarily male) board members stick to certain behavioural structures when deciding on a new colleague or successor. They try to reproduce themselves and thereby follow a so called homophilous behaviour. This means that an individual is acting in favour of other individuals that are similar to himself (Pearce and Xu 2010). To determine similarity, individuals revert to demographical attributes such as race, age or gender (McPherson and Smith-Lovin 1987). Given an atomistic ownership structure, managers are exposed to fewer obstacles and are enabled to continue this self-producing behaviour. Under an atomistic ownership structure, the managers' idea of future colleagues is opposed to many different interests of the many minority shareholders. From a group-theoretical perspective, the probability that they agree on the same candidate is very low. Large groups tend to get involved in more conflicts than small groups (Forbes and Milliken 1999). The managers' risk of a reclamation of the shareholders against the managers' candidate is therefore lower for the case of dispersed ownership. But a single or a few large owners are expected to have fewer conflicts in the decision process on suitable candidates and to exert their influence on the decision on management board composition. These influential owners appoint candidates that they expect to best represent their interests. Thereby it is possible that the owners' candidate does not fit the existing stereotypes. The blockholder might be an obstacle for the homophilous request of the existing management and is therefore more capable to change existing patterns such as that of male dominance on management boards. A higher ownership concentration consequently results in greater board diversity.

\section{H1: A higher ownership concentration of a company is associated with a higher probability of having at least one woman on the management board.}

One basic assumption of hypothesis 1 is that owners influence the appointment process of management board members and choose those kinds of managers that they expect to best represent their interests. However, those interests might differ among the different types of owners. In short, different types of shareholders have different agendas (Kim et al. 2008; Thomsen and Pedersen 2000). For example, the level of emphasis that an owner places on company performance depends on the ownership type (Chaganti and Damanpour 1991). We distinguish between individual owners (including families), bank and insurance companies, strategic investors such as non-financial corporations ${ }^{5}$ and governmental organisations, and institutional investors such as investment funds, venture capitalists or private equity companies (Dharwadkar et al. 2008; Thomsen and Pedersen 2000).

Individual and family owners are mainly interested in the survival of the company (Berrone et al. 2010; Sraer and Thesmar 2007). Generally, they do not have the opportunity to invest in more than one company due to liquidity restrictions (Anderson and Reeb 2003b). Therefore, their risk aversion is assumed to be high (Andres 2008). One of the best ways to ensure their company's survival is to maintain a highly productive and stable performance (Anderson and Reeb 2003a). To enable and sustain this high performance level, family owners strongly depend on managers who represent their best interests. Hence, they often fall back on family members as their managers (Bennedsen et al. 2006; Cucculelli 
and Micucci 2008). Concerning the impact of family ownership on the percentage of female managers, supply arguments are the strongest drivers (Farrell and Hersch 2005). The pool of potential female managers is naturally higher, since on average, half of a family's members are women. We therefore expect the presence of women in management boards to be higher for companies with individual and family owners.

H2a: The more shares are owned by individuals and families, the higher is the probability of having at least one woman on the management board.

Banks and insurance companies, as well as strategic investors, often have objectives that go beyond the maximisation of their share value. They can optimise their own benefits by improving existing business relations with the company they have invested in. For example, banks may decide to promote their own business as viable lenders and M\&A advisors (Dittmann et al. 2010). Strategic investors might be interested in joint ventures with the company they have invested in or are contractors such as customers or suppliers of their investments. To improve these forms of co-operation, they must ensure that the manager they find in these companies is someone they can work with. To understand this decision process we revert to the social network theory. Researchers found that it is a natural group-building process to pick a member of one's own social network (Jehn et al. 1999). This results in the board composition being a reflection of the deciders social network (Lynall et al. 2003). By choosing people from within their network with similar demographic attributes ${ }^{6}$ such as race or gender (following the homophily principal of McPherson et al. 2001), they expect to maximise the probability that the manager meets their expectations. Due to their homophily-influenced thinking (McPherson et al. 2001) and their social networks as external labour pools, they do not believe in women's ability to be good managers and convenient business partners. Thus, we expect banks and insurance companies, as well as strategic investors, to have a negative impact on the acceptance of women on management boards.

$H 2 b$ : The more shares are owned by banks or insurance companies, the lower is the probability of having at least one woman on the management board.

$H 2 c$ : The more shares are owned by strategic investors such as non-financial companies or the government, the lower is the probability of having at least one woman on the management board.

With institutional investors, we come to a group of owners whose major interest is value maximisation. As professional investors whose only business activity is the management of investments, the success of institutional investors is solely measured by the value proposition of their investments (Thomsen and Pedersen 2000). Their own survival depends on the performance and success of their investments (Chaganti and Damanpour 1991). To achieve this objective, institutional investors exhibit a strong level of activity: they are involved in many strategic decisions related to their investments (e.g., they have a positive effect on the performance sensitivity of CEO compensation (Dharwadkar et al. 2008)). Concerning the kind of decisions institutional investors are involved in, they are usually very active in the sustainable behaviour of the companies they invest in. They divest from companies that do not fulfil their expectations in terms of sustainability. Sustainable companies are expected to be more successful und provide large profits in the long run. The Norwegian Government 
Pension Fund, for example, sold its shares of Wal-Mart due to violations of labour rights. They also terminated their engagements with Boeing and EADS because of involvements in the production of nuclear weapons. The Norwegian fund excludes all companies from their portfolio that do not fulfil its social, ethical and environmental requirements (Simpson et al. 2008). This desire for sustainable change also plays a major role concerning the active involvement of institutional owners in decisions on the companies' corporate governance structure (Carleton et al. 1998). They aim to break open out-dated corporate governance patterns (such as dominantly male management board members) and thereby help to increase the diversity on management boards (Carter et al. 2003) Therefore, we expect that the investment of institutional owners has a positive effect on the presence of women among management board members.

$H 2 d$ : The more shares are owned by institutional owners, the higher is the probability of having at least one woman on the management board.

Institutional owners should be investigated in particular detail when studying a German sample and we must distinguish between national and foreign institutional investors. The bank-orientation of the German corporate governance system (Conyon and Schwalbach 2000; Deeg 2005; Edwards and Nibler 2000; Franks and Mayer 2001) plays a decisive role for national institutional investors. Most of the national institutional investors do not act independently, but are bank subsidiaries (Böhler et al. 2010). As a bank subsidiary, their objectives are aligned with those of the bank. They are embedded in the same social network as banks and therefore access the same primarily male external labour pool when deciding on suitable candidates. Foreign institutional investors, on the other hand, are the genuinely active institutional investors described in the paragraph above. They pursue the objectives of sustainable and long-term oriented value proposition and maximisation. In addition, foreign investors are exposed to higher information costs (Ahearne et al. 2004) and higher monitoring costs in cases of poor governance than local investors (Leuz et al. 2009). It has been shown that the investment decisions of foreign institutional investors are driven by aspects of transparency (Aggarwal et al. 2005). Hence, once an investment has been made, for foreigner institutional owners, it is even more important to implement corporate governance patterns that they can trust. In this way, they avoid the reproduction of the established national management elite, which is primarily male, and use a more diversified external pool of candidates. This increases the probability of a woman being appointed and thereby has a positive impact on the presence of women on the management board.

H3: Only foreign active owners have a positive influence on the probability of having at least one woman on the management board.

\section{Sample and data}

\subsection{Sample definition}

Our initial sample consisted of all companies listed in the German CDAX between 2000 and $2007 .{ }^{7}$ We removed all companies with foreign ISINs, since they have their origin 
in countries with different corporate governance systems (most often one-tier systems) which would complicate comparison across companies. To avoid double-counting, we also removed all companies that were listed twice with their common and their preferred stock. We ended up with 5,455 company years. All our data is hand collected from annual reports such as Hoppensted Aktienführer or the Lexis-Nexis database or by request to the investor relationship departments because no database exists that contains information on the composition of management boards and their members' gender in Germany. Extraction of the details of the corresponding 15,976 management board member positions was completed in the following way: we matched three criteria (first name, surname and residence) to check if any two list entries were for the same person. The data in Hoppenstedt Aktienführer were partly inconsistent and therefore had to be cleaned; for example, the names were often written in different ways due to typographical errors or inconsistent notations for double-barrelled names (e.g., "Hans-Werner", "Hans-W."). Similar inconsistencies were present within the data containing information about area of residence, since sometimes the city and sometimes the suburb was mentioned. To identify possible misleading information, we sorted the list according to first names and then compared each row with the following and previous rows. We double-checked all the cases we were unsure about by collecting information from annual reports. This was made possible since every company listed in the German CDAX must report all members of its management board in the annual report. We repeated the whole procedure for the list sorted by surnames. Following this procedure, we collected data for 5,203 company years.

Based on a list of typical male and female first names, we identified the gender of the 15,976 management board member positions. Whenever the classification was unclear, we investigated the person's gender further. This way, we obtained data for the number of women on management boards. In Table 1, we report annual statistics of the management board members. We report the number of companies whose management boards we found

Table 1: Sample description

\begin{tabular}{lllllll}
\hline \multirow{2}{*}{ Year } & \multirow{2}{*}{ Number of firms } & \multicolumn{2}{c}{ Management board members } & & \multicolumn{2}{c}{ Women on management boards } \\
& & Total number & Average & & Total number & Average \\
\hline 2000 & 709 & 2409 & 3.3977 & & 44 & 0.0183 \\
2001 & 717 & 2373 & 3.3096 & & 49 & 0.0206 \\
2002 & 682 & 2173 & 3.1862 & & 44 & 0.0202 \\
2003 & 646 & 1910 & 2.9567 & & 43 & 0.0225 \\
2004 & 621 & 1793 & 2.8873 & & 38 & 0.0212 \\
2005 & 607 & 1762 & 2.9028 & & 44 & 0.0250 \\
2006 & 610 & 1773 & 2.9066 & & 43 & 0.0243 \\
2007 & 611 & 1783 & 2.9182 & & 44 & 0.0247 \\
All & 5203 & 15976 & 3.0705 & 349 & 0.0218 \\
\hline
\end{tabular}

This table provides general information on the sample. The sample includes the number of companies based on all companies listed in the German CDAX for the specific year, excluding all double listings (common and preferred shares of a company are both listed) and foreign ISINs. We found board information for $95 \%$ of these companies $(5,203$ out of 5,455$)$ 
Table 2: Distribution by industry

\begin{tabular}{|c|c|c|c|c|c|}
\hline \multirow[t]{2}{*}{ Industry } & \multirow[t]{2}{*}{ Number of firms } & \multicolumn{2}{|c|}{$\begin{array}{l}\text { Management board } \\
\text { members }\end{array}$} & \multicolumn{2}{|c|}{$\begin{array}{l}\text { Women on management } \\
\text { boards }\end{array}$} \\
\hline & & Total number & Average & Total number & Average \\
\hline Automobile & 17 & 69 & 4.0588 & 0 & 0.0000 \\
\hline Banks & 10 & 48 & 4.8000 & 1 & 0.0208 \\
\hline Basic resources & 8 & 24 & 3.0000 & 0 & 0.0000 \\
\hline Chemicals & 15 & 58 & 3.8667 & 1 & 0.0172 \\
\hline Construction & 15 & 58 & 3.8667 & 0 & 0.0000 \\
\hline Consumer & 44 & 121 & 2.7500 & 6 & 0.0496 \\
\hline Financial services & 92 & 239 & 2.5978 & 7 & 0.0293 \\
\hline Food \& Beverages & 15 & 36 & 2.4000 & 0 & 0.0000 \\
\hline Industrial & 121 & 352 & 2.9091 & 6 & 0.0170 \\
\hline Insurance & 9 & 61 & 6.7778 & 3 & 0.0492 \\
\hline Media & 40 & 101 & 2.5250 & 2 & 0.0198 \\
\hline Pharma \& Healthcare & 45 & 132 & 2.9333 & 9 & 0.0682 \\
\hline Retail & 28 & 75 & 2.6786 & 1 & 0.0133 \\
\hline Software & 93 & 221 & 2.3763 & 7 & 0.0317 \\
\hline Technology & 30 & 86 & 2.8667 & 1 & 0.0116 \\
\hline Tel ecommunication & 10 & 28 & 2.8000 & 0 & 0.0000 \\
\hline Transportation \& Logistics & 11 & 41 & 3.7273 & 0 & 0.0000 \\
\hline Utilities & 8 & 33 & 4.1250 & 0 & 0.0000 \\
\hline
\end{tabular}

This table presents the distribution of women on German management boards by industry

information on, the total number of managers we analysed and the absolute and average numbers of female managers. Among the 15,976 management board member positions, we found a total of 349 female management board member positions.

Tables 2 and 3 present the distribution of women on German management boards across different industries and companies of different sizes. Table 2 shows that the highest number of women on management boards were found especially in companies affiliated to the pharmaceutical industry, or in consumer goods companies. Two explanations are possible for this effect - the supply and the demand argument. According to the idea of women supply, one might expect more women in industries with more female employees (Hillman et al. 2007). Companies in these industries should have a higher proportion of female board members since we do not expect them to "waste the resources of female talent" by leaving them in lower hierarchy levels or even allowing them to resign from their position at this company (Broome 2008). ${ }^{8}$ The women demand represents the need for women because of women-specific topics. The stakeholders of many companies, such as customers and (potential) employees, are women. To support legitimacy, the board should echo this company environment (Lynall et al. 2003).

The distribution by company size in Table 3 shows that very small companies with less than 100 employees in particular have a higher percentage of women on their management boards. A possible explanation might be that these companies are mostly family businesses which appoint family members to the management board.

Information on the ownership structure is extracted from the Thomson Financial database. This database includes every investor that owns at least $0.5 \%$ of the company's 
Table 3: Distribution by company size

\begin{tabular}{|c|c|c|c|c|c|}
\hline \multirow{2}{*}{$\begin{array}{l}\text { Number of } \\
\text { employees }\end{array}$} & \multirow{2}{*}{$\begin{array}{l}\text { Number of } \\
\text { firms }\end{array}$} & \multicolumn{2}{|c|}{ Management board members } & \multicolumn{2}{|c|}{ Women on management boards } \\
\hline & & Total number & Average & Total number & Average \\
\hline $1-100$ & 104 & 222 & 2.1346 & 11 & 0.0495 \\
\hline $100-500$ & 145 & 367 & 2.5310 & 9 & 0.0245 \\
\hline $500-1000$ & 65 & 170 & 2.6154 & 4 & 0.0235 \\
\hline $1000-5000$ & 119 & 371 & 3.1176 & 10 & 0.0270 \\
\hline $5000-10000$ & 37 & 131 & 3.5405 & 2 & 0.0153 \\
\hline $10000-50000$ & 42 & 200 & 4.7619 & 4 & 0.0200 \\
\hline$>50000$ & 99 & 322 & 3.2525 & 4 & 0.0124 \\
\hline
\end{tabular}

This table presents the distribution of women on German management boards by company size. Size is measured by the number of employees

common stock. In case of obvious inconsistencies, we double-checked the data with information from the Hoppenstedt Aktienführer or from annual reports, and made corrections if necessary. Regarding the adjusted sample, we achieved an availability of 4,170 company years. Board characteristics such as size and tenure of the supervisory board were extracted from Hoppenstedt Aktienführer in the same way as the information on management board members. To measure the supervisory board members' tenure for the first years of our samples correctly, we went even further back in time and collected data starting in 1992. Company characteristics such as the number of employees, performance and information on the companies' diversification were collected from Thomson Datastream Worldscope and are available for between 4,561 and 5,267 company years.

Due to the need for simultaneous availability of all the variables used, we ended up with 3,678 company years for our multivariate regression models.

\subsection{Variables}

The endogenous variable in our statistical models is female manager. This is a dummy variable indicating if the specific company has a woman among the management board members.

The exogenous variables can be categorised as either ownership, board or company characteristics. The determination of the endogenous and exogenous variables is based on the recent research explaining the presence of women on boards (Gregoric et al. 2010; Harrigan 1981; Hillman et al. 2007).

Within the variables of ownership structures, we analysed the impact of the freefloat and in further models distinguish between four different types of owners as follows: individual investors that include individual owners or families such as the Porsche family; banks and insurance companies; strategic investors such as corporations or government agencies; and institutional investors such as investment funds, private equity investors, venture capitalists and hedge funds. For the active owners, we also distinguished between institutional investors national, indicating that the owners are based in Germany, and institutional investors foreign, for owners based abroad. All ownership variables are expressed in percentage and indicate which percentage of the shares is held by the specific type of owner. 
In addition, we controlled for the following management and supervisory board characteristics: size management board represents the number of management board members, size supervisory board counts the number of shareholder representatives in the supervisory board ${ }^{9}$ and codet indicates the type of codetermination. This variable can take the values zero (in the case of no codetermination), 0.5 (in the case of one-third codetermination) and one (in the case of parity codetermination). Tenure is the average tenure of all shareholder representatives on the supervisory board.

For company-specific control variables, we considered size, which is approximated through the natural logarithm of the number of employees; diversification, for which we counted the number of industries the company is conducting business with based on the four-digit SIC logic; leverage as the ratio of total debt to the sum of total debt and common equity; founded age as the companies' age; and among our robustness checks, performance as the ROIC (return on invested capital) of the company. In every model, we additionally controlled for industry affiliation based on the information provided by the German stock exchange. Table 4 summarises all used variables, their means, medians

Table 4: Data description

\begin{tabular}{llrrrrr}
\hline Variable & $\begin{array}{l}\text { No. of } \\
\text { observations }\end{array}$ & Mean & Median & VIFs 1.1 & VIFs 1.2 & VIFs 1.3 \\
& & & & & & \\
\hline Ownership Structure & 4170 & 41.4305 & 38.0600 & 1.0822 & & \\
Freefloat & 4170 & 22.5603 & 8.4150 & & 1.9694 & 1.9695 \\
Individual investors & 4170 & 0.9063 & 0.0000 & & 1.1201 & 1.1201 \\
Banks and Insurance companies & 4170 & 24.7178 & 7.2700 & & 2.0890 & 2.0915 \\
Strategic investors & 4170 & 10.3851 & 4.8650 & & 1.5557 & \\
Institutional investor & 4170 & 5.8508 & 1.7900 & & & 1.2910 \\
Institutional investor national & 4170 & 4.5343 & 0.0000 & & & 1.3376 \\
Institutional investor foreign & & & & & & \\
Board Characteristics & 5203 & 0.0661 & 0.0000 & - & - & - \\
Female manager (0,1) & 5203 & 3.0705 & 3.0000 & 2.0002 & 2.0136 & 2.0141 \\
Size management board & 5268 & 4.7764 & 4.0000 & 2.2243 & 2.2928 & 2.2952 \\
Size supervisory board & 5267 & 0.3144 & 0.0000 & 3.1730 & 3.2031 & 3.2073 \\
Codetermination (0,0.5,1) & 5267 & 3.2237 & 3.0000 & 1.4327 & 1.4668 & 1.4746 \\
Tenure & & & & & & \\
Firm Characteristics & 4561 & 6.6048 & 6.4907 & 3.8052 & 3.8236 & 3.8242 \\
Size & 5240 & 3.7664 & 3.0000 & 1.5045 & 1.5139 & 1.5210 \\
Diversification & 5267 & 4.8086 & 6.7200 & - & - & - \\
Performance & 4672 & 0.2106 & 0.1528 & 1.1498 & 1.1535 & 1.1536 \\
Leverage & 5247 & 48.8938 & 22.0000 & 1.6334 & 1.6541 & 1.6565 \\
Founded Age & & & & & & \\
\hline
\end{tabular}

This table provides descriptive statistics for the companies in our sample. The initial sample consisted of 6,295 company years for the years 2000 to 2007, whereas the descriptive statistics for the single variables were based on individual numbers of company years, depending on the availability, range between 4,170 and 5,267 company years. Companies are included when they are listed at the CDAX of the German stock exchange for the specific year, excluding all double listings (common and preferred shares of a company are both listed) and foreign ISINs. The table represents the mean, median and the variance inflation factors of regression model 1.1-1.3 
and standard deviations. A table of variable descriptions and the used sources per variable can be found in Table 6 in the appendix. Additionally, Table 4 contains the variance inflation factors (VIFs) of our regression models to challenge potential problems of multicollinearity. A discussion of the values can be found in paragraph 5.3.

\section{Empirical analyses}

To test our hypotheses, we created a logistic regression model. We introduced the empirical design, discuss our empirical results and closed with robustness tests.

\subsection{Empirical design}

To investigate the impact of ownership characteristics on the representation of women in management boards empirically, we analysed several variants of the following multivariate model specification:

$$
\begin{gathered}
\text { Female manager }=\mathrm{f} \text { (ownership structure, board characteristics, } \\
\text { company characteristics })
\end{gathered}
$$

Since the endogenous variable of our model — female manager — is a binary variable, we used a logistic regression (Hoetker 2007). To investigate the impact of the ownership structure, we took the following three-step approach: the control variables for board and company characteristics are included in every model. To measure the impact of the owners' model, model 1.1 only contains freefloat. In model 1.2, we replaced freefloat with the four variables indicating the type of owner: individual investors, banks and insurance companies, strategic investors and institutional investors. For model 1.3, we chose a more detailed classification of the active owners using the variables institutional investors national and institutional investors foreign.

To challenge the model quality, we also considered the possible problems of heteroscedasticity and multi-collinearity. To resolve the problem of heteroscedasticity, we used Huber/White (QML) standard errors (Freedman 2006), and to detect potential problems of multi-collinearity, we calculated the variance inflation factors (VIFs) for all models.

\subsection{Empirical results}

Table 5 represents the results of the estimation of our logit-model.

Model 1.1 shows that ownership concentration (defined as 1 minus freefloat in percent divided by 100) generally has no statistically significant effect on the likelihood of having a woman among the management board members. This means that we cannot give evidence if the existence of a dominant owner affects the probability of having at least one female manager, meaning that hypothesis 1 cannot be confirmed.

The influence of specific types of owners is investigated in models 1.2 and 1.3. Both models show that individual investors have a significant positive effect on the probability of having at least one woman among the management board members. Therefore, hypothesis $\mathrm{H} 2 \mathrm{a}$ can be confirmed: private owners have more female representatives on the management boards of the companies they own. However, shares owned by banks and insurance 


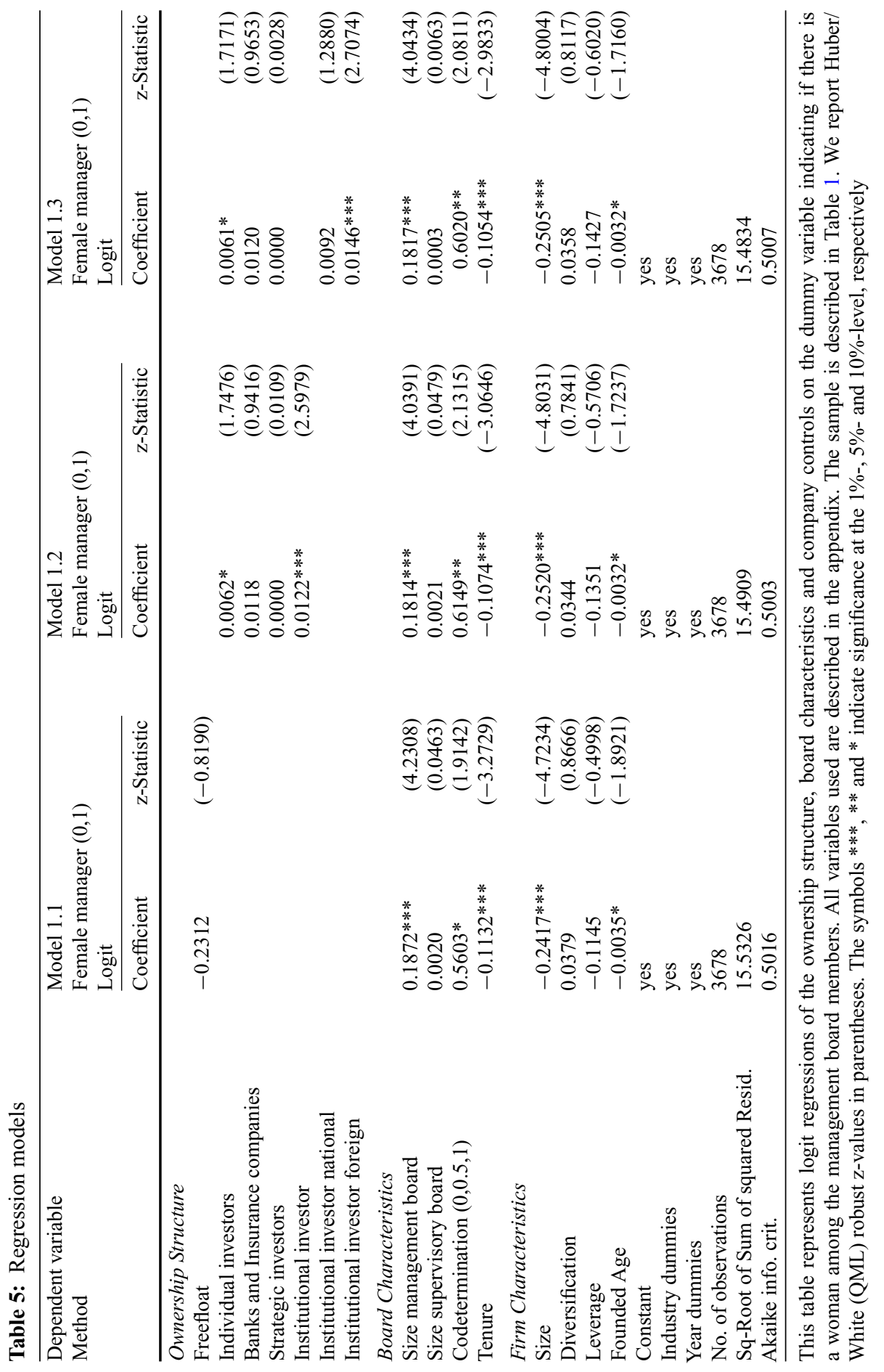


companies and strategic investors do not have any significant effect on the probability of having at least one woman among the management board members. Hence, hypotheses $\mathrm{H} 2 \mathrm{~b}$ and $\mathrm{H} 2 \mathrm{c}$, which stated that male-dominated banks and corporations mainly support male managers, cannot be confirmed. Moreover, the signs of both coefficients are positive, and not negative as expected. However, since the coefficients are not significant in any model, we were not able to show a positive effect of either banks and insurance companies or strategic investors.

The effect of institutional investors on the probability of having at least one woman among the management board members in model 1.2 is significantly positive. That is to say, hypothesis $\mathrm{H} 2 \mathrm{~d}$ can be confirmed: active owners positively affect the strategic decisions concerning the management board's composition. This result is consistent with the studies by Carleton et al. (1998) and Farrell and Hersch (2005).

The separate consideration of national and foreign active investors can be found in model 1.3. The regression demonstrates that the positive effect of active owners on the probability of having at least one woman among the management board members only holds for owners based abroad, and not for the German ones. The variable institutional investors foreign has a significantly positive coefficient, whereas the positive coefficient of institutional investors national is not significant. This results in a confirmation of hypothesis $\mathrm{H} 3$.

The results for our control variables are the following: the size of the management board has a positive effect on the probability of having a woman on the management board. This is feasible since the possibility to enhance diversity is higher in larger groups. We also find a positive effect of codetermination on the probability of having a woman on the management board. This might be caused by the presence of union representatives who increase the companies' awareness of the importance of equality. For the average tenure of the management board members we find a significant negative effect on the probability of having at least one woman on the management board. This result can be explained via the stability of the board composition, at which the high tenure can be seen as an approximation for stability. The more fluctuation a board has, the higher the possibility to also appoint a woman at some point of time.

Additionally the company control variables support the idea of young and small companies having women on the management board more frequently: the company size has a significantly negative coefficient also the influence of the founded age is significantly negative.

\subsection{Model quality and robustness tests}

To challenge the model quality, we paid attention to the potential problems of heteroscedasticity and multi-collinearity. To resolve the heteroscedasticity problem, we used $\mathrm{Hu}-$ ber/White (QML) standard errors (Freedman 2006). Multi-collinearity is not of concern since, apart from codetermination and company size, the variance inflation factors (VIFs) do not exceed 3. The VIFs for model 1.3 are displayed in Table 4.

To examine the robustness of our results, we considered the following three dimensions: selection bias, choice of endogenous variable and choice of exogenous variables. ${ }^{10}$ All robustness tables can be found in the appendix. 
To eliminate any concerns about a selection bias driven by the lower availability of ownership data, we used a Heckit regressions model that includes a Heckman correction term. Following Sigelman and Zeng's (1999) example, we took a two-step approach to build a Heckit model (Siegelman and Zeng 1999). In the first step we performed a logit regression model with the existence of ownership data as the binary dependent variable. We used year dummies as explanatory variables within this model and a HDAX dummy and an event variable to explain the probability of missing ownership data. The year dummies should control for time effects, the HDAX-dummy ${ }^{11}$ for potential size effects and the event variable for events such as delisting, insolvency, etc. that could lead to missing data. The event variable is a count variable (with a maximum value of ten), which counts the number of company years for which data are available within the Hoppenstedt Aktienführer. Because the Hoppenstedt Aktienführer is supposed to cover all Germanlisted companies, we expect that missing years are an appropriate proxy for special events such as delistings or insolvencies. In the second step, we used the results of the logit regression to calculate the inverse Mills ratios. We then expanded our regression models 1.1-1.3 by including the inverse Mills ratio as an additional independent variable. As Table 7 in the appendix shows, our results remain qualitatively identical. Therefore, we exclude sample selection biases within our regression models.

To consider the robustness of the endogenous variable, we replaced the dummy variable female manager with number of female managers. Since we thereby replaced a binary variable with a count variable, changes in terms of methodology were also necessary. Models explaining count variables are calculated using a poisson regression (Farrell and Hersch 2005). Our results are also qualitatively stable for this change (see Table 8 in the appendix). The results are therefore robust concerning the choice of the endogenous variable.

With respect to the choice of exogenous variables, we made two changes: First, we calculated our models without the variable codetermination. Second, we included a performance measure in our models. Tables 9 and 10 in the appendix show that neither of these two changes had an effect on our results. Our results can therefore be considered as robust in relation to the choice of exogenous measures.

\section{Discussion}

This paper analyses the impact of ownership structure on the presence of women on management boards. In 2007, just $2.47 \%$ of the management board members of German companies were female. In other words, German companies do not use nearly $50 \%$ of the country's intellectual capacity in management positions. The purpose of our study was to investigate if ownership concentration and the specific type of owner have had an influence on this percentage.

We arrived at the following results. We did not find any evidence that ownership concentration influences the presence of women on management boards. As argued in our hypotheses strong owners have the power to influence the composition of the management board and thereby as the case may be disturb the reproduction of same types of managers over generation. Our results however do not show any significantly positive impact on the 
presence of women among management board members. This means that the power to have the possibility for change is not enough. Owners also need a special interest to favor female managers. We therefore distinguished between different types of investors and we found significant positive effects on the presence of women on management boards; the concentration of individual as well as institutional owners positively affects the probability of having female management board members. However our results do not show any evidence for a negative effect of banks and insurance companies or strategic investors on the presence of women on management boards. The demographic reflection of the social network of the deciders in banks and strategic investors seems to be non-existent for the case of management board compensation. A further separation of the institutional owners into national and foreign owners illustrates that only the foreign institutional owners drive the positive effect. It is not only important to be an institutional owner but it is also of relevance what kind of institutional experiences the active owner bases its behaviour on. German-based funds are directly confronted with a family policy that detracts female careers, and thus they do not dare to force women into management positions. In contrast, foreign investors know that careers are possible for females and therefore they actively support them.

This research study adds to the recent public and political discussion in the following way: We have shown that specific corporate governance institutions exist-blockholders and in particular families and foreign institutional owners - who act in favour of women on management boards. However, it is unclear if their effect is strong enough to enable the country's regulators to relinquish on further actions. One specific measure that is often discussed in this regard is a binding quota regulation as already implemented for example in Norway (Ahern and Dittmar 2010; Bøhren and Strøm 2010; Gregoric et al. 2010). Whether this is an effective measure was not part of our investigation and has to be critically debated by politicians. In this debate, legislators should contrast the many disadvantages of quota regulations with the alleged advantage of increasing the number of female board members. By forcing companies to recruit a specific number of women onto their boards, the numbers will grow. But will the situation of women in management positions improve sustainably? Actions against discrimination quite often result in reinforcement of prejudices and stereotypes (Coate and Loury 1993; Franck and Jungwirth 1998). Women who have achieved management positions as a result of the quota regulation will be exposed to the general suspicion of being a "quota woman". Moreover, many opportunities remain for male managers to exclude women from important decisions, such as through informal meetings that the legislator cannot regulate.

For a sustainable reform of female career opportunities, the legislator is strongly dependent on the commitment and the will of the companies. Instead of implementing the hard law of a quota, soft laws might be a possibility to boost the companies' commitment (Aguilera et al. 2008). One possibility of a soft law would be the following extension of the Corporate Governance Codex: companies could be forced to publish the percentage of women included in the first three management levels. As a result, an external social pressure could be created for companies with few or no women among their managers and directors. The resulting disadvantages of this social pressure for the companies would include negative profiling on the labour market for young female talent and the possible loss of image amongst female customers. Currently, the German Corporate Governance Codex 
only stresses adequate consideration in management and supervisory boards (Weber-Rey 2009).

For companies our research results have the following consequences. The evaluation of the company by the capital market is of high relevance. Since there is actually no type of owners that is acting against the favour of women in management position, they do not have to fear penalisation of the capital market of measurements to increase career opportunities of women in their company.

\section{Study limitations and future research suggestions}

This paper is not without limitations: First, we used only publically available data. Using data originating from databases such as Datastream and annual reports, we were able to model good indicators for owners' behaviour concerning the support of women in top management positions. However, we did not concretely measure their preferences at an individual level. To do so, in-depth interviews with representatives of the owners would be necessary. Admittedly, this kind of data often affiliates with strong selection biases. Only persons who are affected by the issue of interest, or are actively interested in the topic of the interview, are willing to participate. In summary, neither of the two methods might be able to extract the pure investors' preferences and behaviour without any measurement issues. We decided to suspend the bias due to the willingness to participate in interviews, and in return to accept the high level of abstraction of the publically available data on company level. Nevertheless, interview-based investigations in this field of research might be an interesting extension to our study and provide a direction for future research. Second, our analyses investigated which factors explain the presence of women on management boards (the probability of having been appointed and not having been dismissed). Another possible investigation could be the analysis of concrete appointment decisions. However, to have a representative number of cases, a larger sample would be necessary. Extending the given sample to the future would probably result in biases due to the recently intensified public discussion on quota regulations. But this could also be an advantageous opportunity to measure and investigate quota effects. This brings us to the third limitation: While we provide further insights on the mechanisms that increase the percentage of women on management boards, we do not answer the question of whether a quota regulation could be effective and whether it is needed. One way to approach this research question would be the extension of the analysis over more countries, covering some societies that have already introduced a quota regulation. Such investigation of an international sample would also enable researchers to identify institutional drivers, such as the impact of a country's family policy on the presence of women in top management positions. Research of this kind might also enable evaluating family political mechanisms and give answers on the question why Germany still has very few women in management positions though housekeeping expenses are deductable from income tax. Fourth, in our study, we only focused on the highest possible management positions - the management board. An analysis of drivers - institutional or organisational - of women in middle management positions would supplement our research and give companies concrete advice on how to increase the percentage of women at every hierarchical level. 
Beyond that, our paper provides possible directions for future research on board diversity: For example, our analyses could be extended to include other diversity dimensions. The gender variable used in our study is only one demographical category (Randel 2002) and could be extended to include age or nationality. Investigation of diversity in terms of educational and professional background would also further broaden our knowledge of the drivers and impacts of diversity in top management teams. In particular, research covering more than one diversity dimension simultaneously would be of high relevance. The underlying theoretical concept might hereby be the theory of faultlines (Tuggle et al. 2010).

\section{Endnotes}

$1 \mathrm{http}: /$ www.welt.de / wirtschaft / article12923472/Ministerin-lobt-Frauenfoerderung-deutscherFirmen.html, 15.06.2011.

2 Compare e.g. Elston and Goldberg (2003) and Rapp and Wolff (2010) on the influence of owners on aspects of management compensation (Elston and Goldberg 2003; Rapp and Wolff 2010) or Carleton et al. (1998) and Chizema and Kim (2010) on the impact of owners on the board composition (Carleton et al. 1998; Chizema and Kim 2010).

3 Our empirical research is based on a German sample. The German corporate governance system is a two-tier system. It distinguishes between management board members - comparable to the executive board members in the Anglo-Saxon one-tier system used in the U.S. - and supervisory board members - the outside board members in the U.S. system (Baums and Scott 2005; Douma 1997). Our empirical investigation focuses on management board members.

4 Most of the papers cited analyse the drivers for women on boards or women in top management teams. The majority of papers analysing women on boards are based on US data. Since the US has a one-tier corporate governance system, in contrast to Germany, no further separation into management and supervisory board members can be achieved.

5 For the consideration of non-financial companies as strategic investors also compare with Andres (2008).

6 British studies showed that banking was 2007 with 14\% women among all board members the 5th out of ten industries concerning female representatives on board (Sealy et al. 2007). For German numbers compare Table 2 of this article. 2007 only two percent of the management board members of banks and five percent of insurance management board members were female.

7 The CDAX is the Composite Deutscher Aktien Index, which includes all companies fulfilling the Prime or General Standard at the Frankfurt Stock Exchange. In Europe, companies can generally choose between two different points of access to equity capital markets. Beside an EU-regulated market, most exchanges offer a market regulated by itself. The two markets differ with respect to legal basis and status, but also with respect to differences in transparency requirements. Within the EU-regulated market, the Frankfurt Stock Exchange (FWB - Frankfurter Wertpapierbörse), which is the most important German stock exchange, allows companies to be listed in one of two different market segments. While companies willing to fulfil the EU-regulated minimum transparency level only have to be listed in the General Standard, companies opting for a listing in the Prime Standard must fulfil additional transparency requirements. Accordingly, the Prime Standard is the market segment with the highest reporting and disclosure level at the most important German stock exchange. 
8 An additional supply-driven argument bases on the age of companies: In young companies the hierarchies are still flat. The probability for a woman working in this young company to become a member of the management is therefore greater. This explains e.g. the relatively high percentage of women on management boards in the software industry.

9 The German law imposes some restrictions concerning the size of the supervisory board. The maximum size allowed depends on the equity capital: for more than ten millions in equity the maximum number of supervisory board members is 21 , for between 1,5 and ten million, it is 15 members and for less than 1,5 nine members are allowed at maximum ( $\$ 95 \mathrm{AktG}$ ). For codetermined companies there are additional rules depending on the number of employees in Germany: in the case of more than 20.000 employees the company has to have more ten shareholder representatives (and ten employee representatives), between 10,000 and 20,000 the imposed number of shareholder representatives is eight (and eight employee representatives) and for between 2,000 and 10,000 employees companies must have six shareholder and six employee representatives (§ 7(1) MitbestG.). However, the variance inflation factors (Table 4) show that multi-collinearity due to the close relation to firm size is not a problem and does not affect our empirical model quality.

10 To challenge the robustness of the used method, a logit regression, we additionally conduct a propensity score matching according to Becker and Ichino (2002). We first determined a control group for the companies with women on their management boards based on the control variables used in model 1.3 and calculated the t-values for the important ownership variables (Becker and Ichino 2002) using the nearest neighbourhood approach (Ivanov and Xie 2010). With t-values of 1.55 for individual investor 1.53 for institutional investor, and 1.89 for institutional investor foreign the first two variables are almost significant and the third is significant to a level of $10 \%$. Our results can therefore be considered as robust regarding the choice of method.

11 The HDAX-dummy takes the value of one if the company was listed in the HDAX-Index, which is a combination of the three important German indices DAX, MDAX. After the index restructuring, this index also included the TecDAX. 


\section{Appendix}

Table 6: Definition of variables and data sources

\begin{tabular}{|c|c|c|}
\hline Variable & Description & Source \\
\hline \multicolumn{3}{|l|}{ Ownership Structure } \\
\hline Freefloat & $\begin{array}{l}\text { Percentage of shares that are } \\
\text { not owned by blockholder }\end{array}$ & $\begin{array}{l}\text { Thomson } \\
\text { Datastream/Worldscope, annua } \\
\text { reports }\end{array}$ \\
\hline Individual investors & $\begin{array}{l}\text { Percentage of shares that are } \\
\text { owned by individual and family } \\
\text { owners }\end{array}$ & $\begin{array}{l}\text { Thomson } \\
\text { Datastream/Worldscope, annua } \\
\text { reports }\end{array}$ \\
\hline $\begin{array}{l}\text { Banks and Insurance } \\
\text { companies }\end{array}$ & $\begin{array}{l}\text { Percentage of shares that are } \\
\text { owned by banks and inssurance } \\
\text { companies }\end{array}$ & $\begin{array}{l}\text { Thomson } \\
\text { Datastream/Worldscope, annua } \\
\text { reports }\end{array}$ \\
\hline Strategic investors & $\begin{array}{l}\text { Percentage of shares that are } \\
\text { owned by other non-financial } \\
\text { corporations or governemental } \\
\text { organizations }\end{array}$ & $\begin{array}{l}\text { Thomson } \\
\text { Datastream/Worldscope, annua } \\
\text { reports }\end{array}$ \\
\hline Institutional investor & $\begin{array}{l}\text { Percentage of shares that are } \\
\text { owned by institutional owners }\end{array}$ & $\begin{array}{l}\text { Thomson } \\
\text { Datastream/Worldscope, annua } \\
\text { reports }\end{array}$ \\
\hline $\begin{array}{l}\text { Institutional investor } \\
\text { national }\end{array}$ & $\begin{array}{l}\text { Percentage of shares that are } \\
\text { owned by institutional owners } \\
\text { based in Germany }\end{array}$ & $\begin{array}{l}\text { Thomson } \\
\text { Datastream/Worldscope, annua } \\
\text { reports }\end{array}$ \\
\hline $\begin{array}{l}\text { Institutional investor } \\
\text { foreign }\end{array}$ & $\begin{array}{l}\text { Percentage of shares that are } \\
\text { owned by institutional owners } \\
\text { based abroad }\end{array}$ & $\begin{array}{l}\text { Thomson } \\
\text { Datastream/Worldscope, annua } \\
\text { reports }\end{array}$ \\
\hline \multicolumn{3}{|l|}{ Board Characteristics } \\
\hline Size management board & $\begin{array}{l}\text { Number of management board } \\
\text { members }\end{array}$ & $\begin{array}{l}\text { Hoppenstedt Aktienführer, } \\
\text { annual reports }\end{array}$ \\
\hline Size supervisory board & $\begin{array}{l}\text { Number of supervisory board } \\
\text { members (shareholder } \\
\text { representatives) }\end{array}$ & $\begin{array}{l}\text { Hoppenstedt Aktienführer, } \\
\text { annual reports }\end{array}$ \\
\hline Codetermination $(0,0.5,1)$ & $\begin{array}{l}\text { Variable that indicates the kind } \\
\text { of codetermination existing in } \\
\text { the company; equals zero in } \\
\text { case of no codetermination, } 0.5 \\
\text { in case of one-third } \\
\text { codetermination and } 1 \text { in case } \\
\text { of parity codetermination }\end{array}$ & $\begin{array}{l}\text { Hoppenstedt Aktienführer, } \\
\text { annual reports }\end{array}$ \\
\hline Tenure & $\begin{array}{l}\text { Average tenure of supervisory } \\
\text { board members (shareholder } \\
\text { representatives) in years }\end{array}$ & $\begin{array}{l}\text { Hoppenstedt Aktienführer, } \\
\text { annual reports }\end{array}$ \\
\hline
\end{tabular}


Table 6: (continued)

\begin{tabular}{|c|c|c|}
\hline Variable & Description & Source \\
\hline \multicolumn{3}{|l|}{ Firm Characteristics } \\
\hline Size & $\begin{array}{l}\text { Natural logarithm of total } \\
\text { employees }\end{array}$ & $\begin{array}{l}\text { Thomson } \\
\text { Datastream/Worldscope }\end{array}$ \\
\hline Diversification & $\begin{array}{l}\text { Number of business segments } \\
\text { the firm is operating in }\end{array}$ & $\begin{array}{l}\text { Thomson } \\
\text { Datastream/Worldscope }\end{array}$ \\
\hline Performance & Return on invested capital & $\begin{array}{l}\text { Thomson } \\
\text { Datastream/Worldscope }\end{array}$ \\
\hline Leverage & Debt-equity-ratio & $\begin{array}{l}\text { Thomson } \\
\text { Datastream/Worldscope }\end{array}$ \\
\hline Founded-Age & Age since foundation & Annual reports, IR requests \\
\hline Industrie Affiliation & $\begin{array}{l}\text { Dummy variables that indicated } \\
\text { industry affiliation }\end{array}$ & German Stock Exchange \\
\hline
\end{tabular}

This table describes the set of variables used for our analyses 


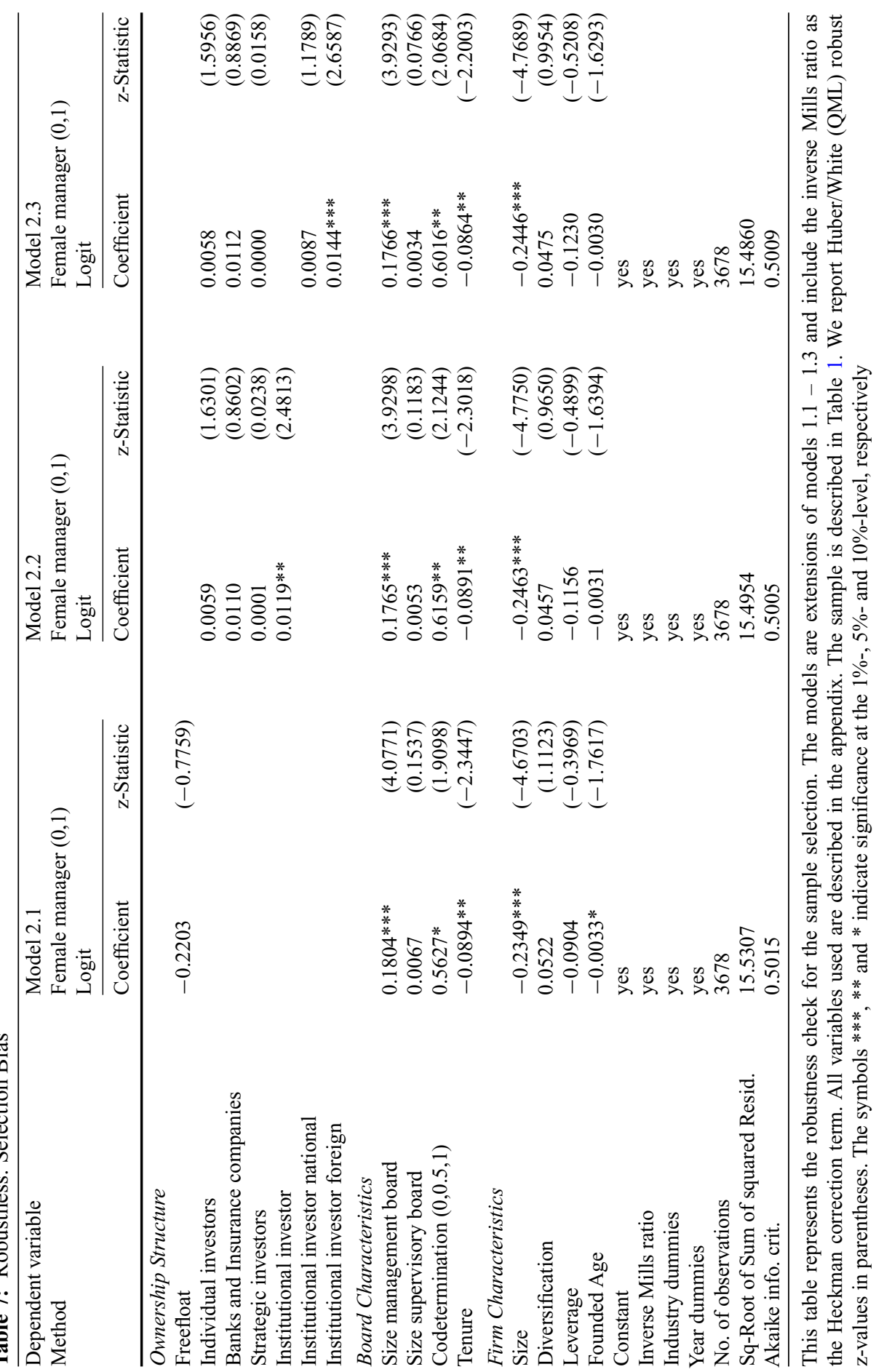




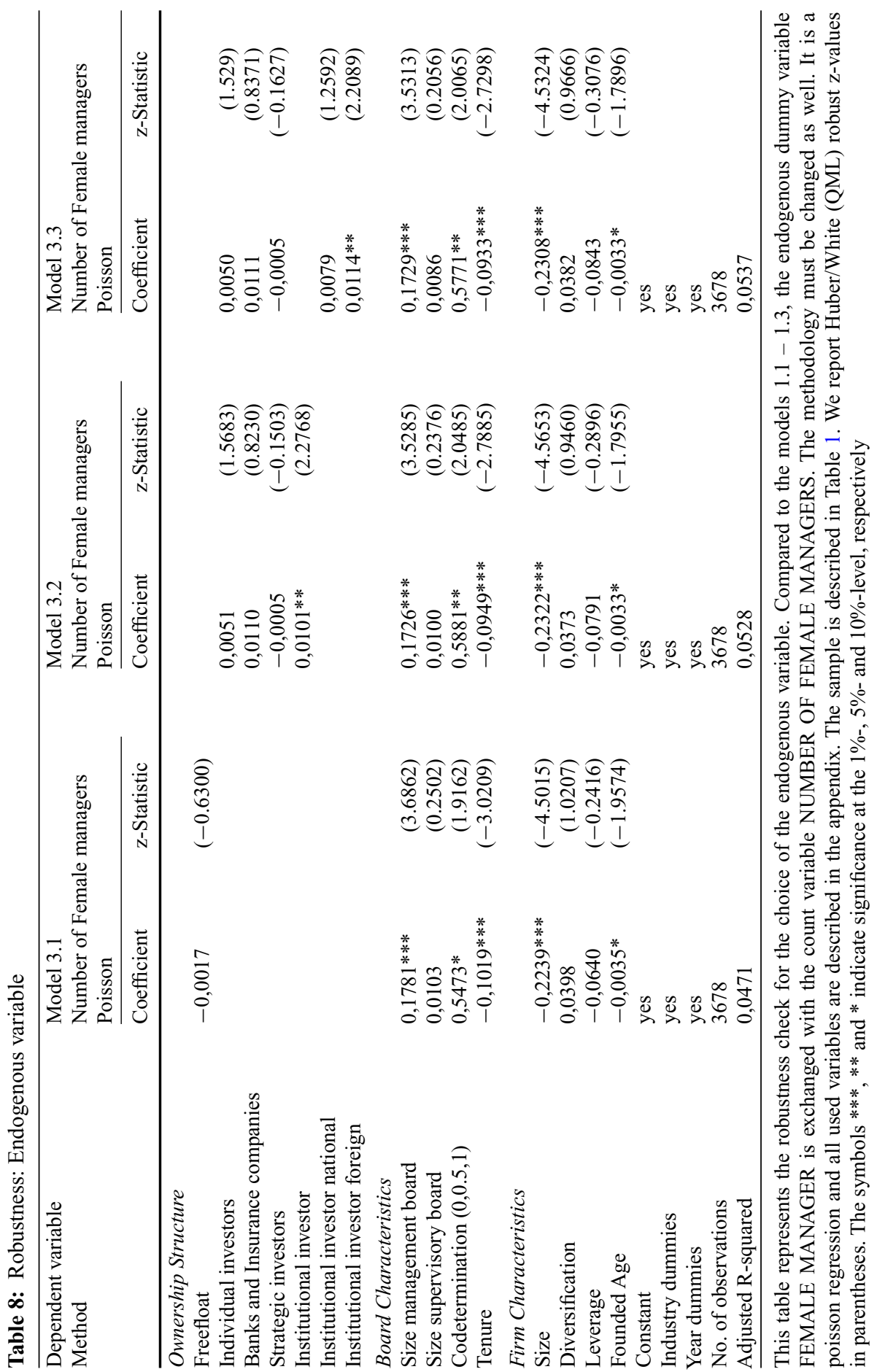




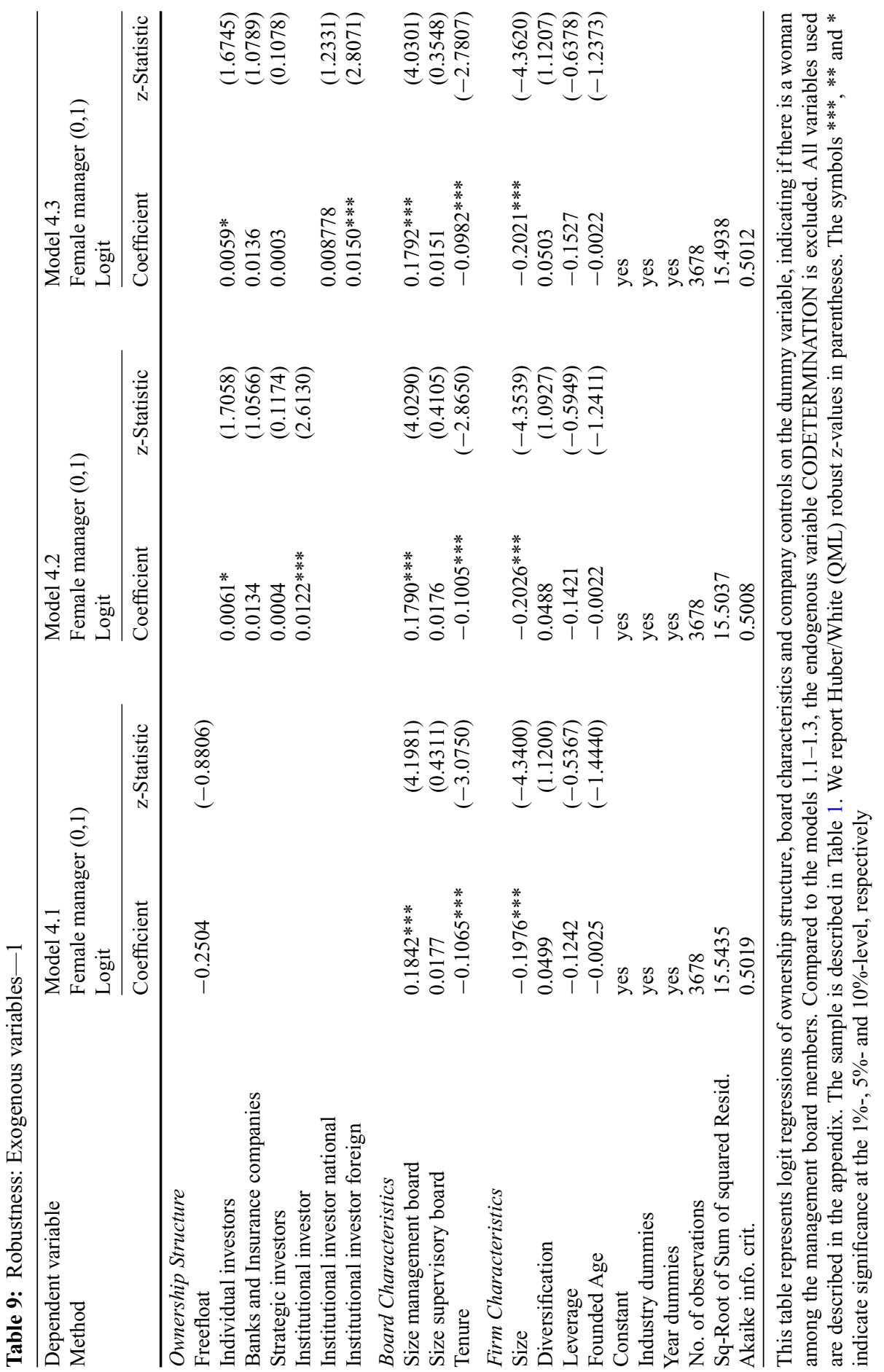




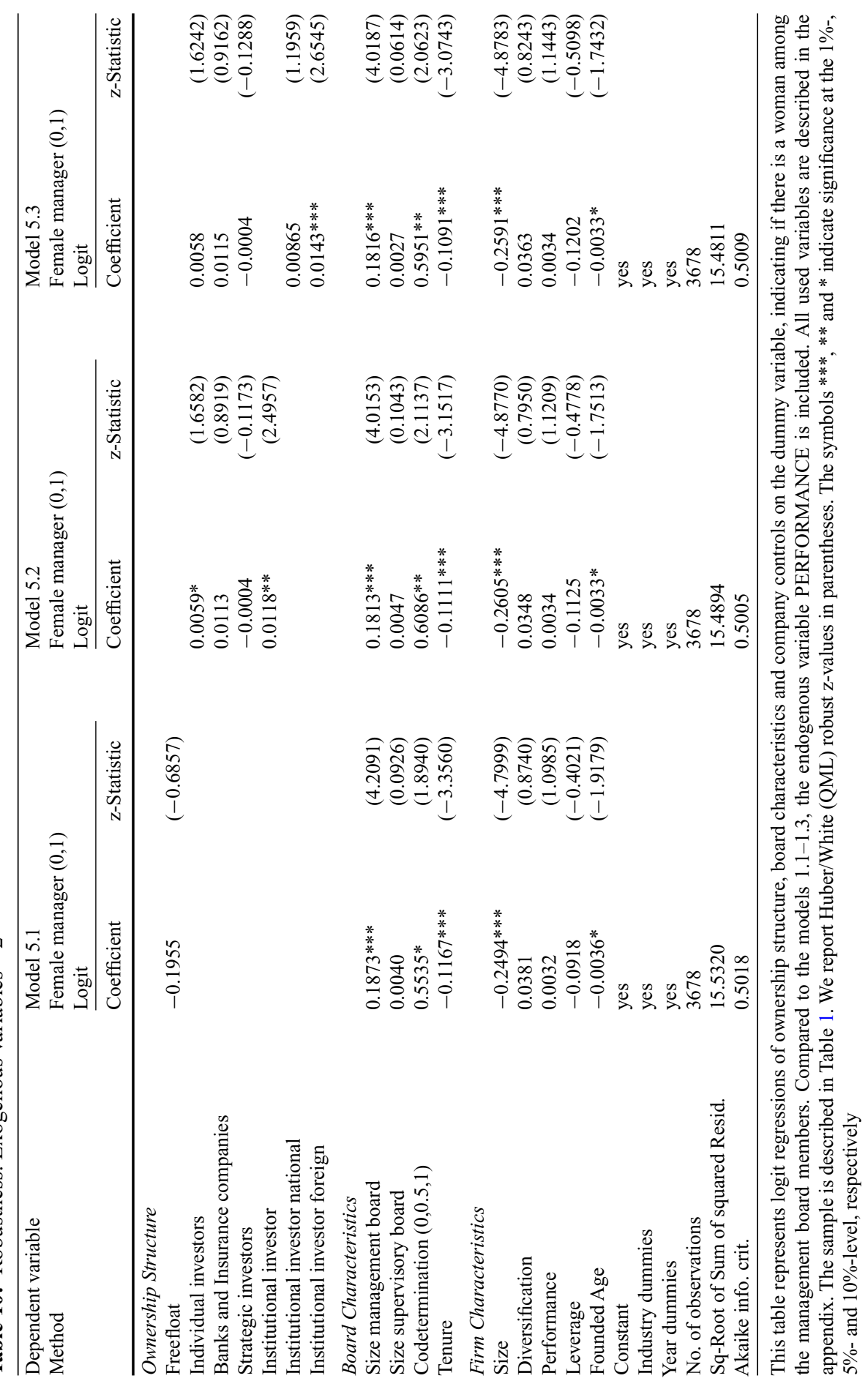


Open Access: This article is distributed under the terms of the Creative Commons Attribution Noncommercial License which permits any noncommercial use, distribution, and reproduction in any medium, provided the original author(s) and source are credited.

\section{References}

Adams RB, Ferreira D (2009) Women in the boardroom and their impact on governance and performance. J Finan Econ 94:291-309. doi:10.1016/j.jfineco.2008.10.007

Aggarwal R, Klapper L, Wysocki PD (2005) Portfolio preferences of foreign institutional investors. J Bank Financ 29:2919-2946. doi:10.1016/j.jbankfin.2004.09.008

Aguilera RV, Filatotchev I, Gospel H, Jackson G (2008) An organizational approach to comparative corporate governance: costs, contingencies, and complementarities. Organ Sci 19:475-492. doi:10.1287/orsc. 1070.0322

Ahearne AG, Griever WL, Warnock FE (2004) Information costs and home bias: an analysis of US holdings of foreign equities. J Int Econ 62:313-336. doi:10.1016/S0022-1996(03)00015-1

Ahern KR, Dittmar AK (2010) The changing of the boards: the value effect of a massive exogenous shock. Mendeley 1001:49

Anderson RC, Reeb DM (2003a) Founding-family ownership and firm performance: evidence from the S \& P 500. J Financ 58:1301-1327. doi:10.1111/1540-6261.00567

Anderson RC, Reeb DM (2003b) Founding-family ownership, corporate diversification, and firm leverage. J Law Econ 46:653-684. doi:10.1086/377115

Andres C (2008) Large shareholders and firm performance — an empirical examination of foundingfamily ownership. J Corp Financ 14:431-445. doi:10.1016/j.jcorpfin.2008.05.003

Aretz H-J, Hansen K (2003) Erfolgreiches Management von Diversity. Die multikulturelle Organisation als Strategie zur Verbesserung einer nachhaltigen Wettbewerbsfähigkeit. Z Personalforschung 17:9-36

Arfken DE, Bellar SL, Helms MM (2004) The ultimate glass ceiling revisited: the presence of women on corporate boards. J Bus Ethics 50:177-186

Barclay MJ, Holderness CG, Sheehan DP (2009) Dividends and corporate shareholders. Rev Financ Stud 22:2423-2455. doi:10.1093/rfs/hhn060

Barth E, Gulbrandsen T, Schone P (2005) Family ownership and productivity: the role of ownermanagement. J Corp Financ 11:107-127. doi:10.1016/j.jcorpfin.2004.02.001

Baums T, Scott KE (2005) Taking shareholder protection seriously? Corporate governance in the United States and Germany. Am J Comp Law 53:31-75

Becker GS (1985) Human capital, effort, and the sexual division of labor. J Lab Econ 3:33-58

Becker SO, Ichino A (2002) Estimation of average treatment effects based on propensity scores. Stata J 2:358-377

Bennedsen M, Nielsen KM, Pérez-Gonzàlez F, Wolfenzon D (2006) Inside the family firm: the role of families in succession decisions and performance. Quart J Econ 122:647-691

Berle AA, Means GC (1968) The modern corporation \& private property. Transaction Publishers, New Brunswick

Berrone P, Cruz C, Gomez-Mejia LR, Larraza-Kintana M (2010) Socioemotional wealth and corporate responses to institutional pressures: do family-controlled firms pollute less? Adm Sci Q 55:82-113. doi:10.2189/asqu.2010.55.1.82

Brammer S, Millington A, Pavelin S (2009) Corporate reputation and women on the board. Br J Manag 20:17-29. doi:10.1111/j.1467-8551.2008.00600.x

Broome LL (2008) The corporate boardroom: still a male club. J Corp Law 33:665-680

Böhler D, Rapp MS, Wolff M (2010) Foreign investors as a mechanism to resolve domestic director networks - evidence from the Germany Inc. Networks

Bøhren Ø, Strøm RØ (2010) Governance and politics: regulating independence and diversity in the board room. J Bus Financ Account 37:1281-1308. doi:10.1111/j.1468-5957.2010.02222.x 
Carleton WT, Nelson JM, Weisbach MS (1998) The influence of institutions on corporate governance through private negotiations: evidence from TIAA-CREF. J Financ 53:1335-1363

Carter DA, Simkins BJ, Simpson WG (2003) Corporate governance, board diversity, and firm value. Financ Rev 38:33-53. doi:10.1111/1540-6288.00034

Chaganti R, Damanpour F (1991) Institutional ownership, capital structure, and firm performance. Strateg Manag J 12:479-491

Chizema A, Kim J (2010) Outside directors on korean boards: governance and institutions. J Manag Stud 47:109-129. doi:10.1111/j.1467-6486.2009.00868.x

Coate S, Loury GC (1993) Will affirmative-action policies eliminate negative stereotypes? Amer Econ Rev 83:1220-1240

Conyon MJ, Schwalbach J (2000) Executive compensation: evidence from the UK and Germany. Long Range Plan 33:504-526. doi:10.1016/S0024-6301(00)00052-2

Cucculelli M, Micucci G (2008) Family succession and firm performance: evidence from Italian family firms. J Corp Financ 14:17-31. doi:10.1016/j.jcorpfin.2007.11.001

Daily CM, Certo ST, Dalton DR (1999) A decade of corporate women: some progress in the boardroom, none in the executive suite. Strateg Manag J 20:93-99

Deeg R (2005) The comeback of modell Deutschland? The new German political economy in the EU. Ger Politics 14:332-353. doi:10.1080/09644000500268795

Denis DJ, Denis DK, Sarin A (1997) Agency problems, equity ownership, and corporate diversification. J Financ 52:135-160. doi:10.2307/2329559

Dharwadkar R, Goranova M, Brandes P, Khan R (2008) Institutional ownership and monitoring effectiveness: it's not just how much but what else you own. Organ Sci 19:419-440. doi: 10.1287 orsc. 1080.0359

Dittmann I, Maug E, Schneider C (2010) Bankers on the boards of german firms: what they do, what they are worth, and why they are (still) there. Rev Financ 14:35-71. doi:10.1093/rof/rfp007

Douma S (1997) The two-tier system of corporate governance. Long Range Plan 30:612-614. doi:10.1016/S0024-6301(97)00047-2

Edwards JSS, Nibler M (2000) Corporate governance: banks versus ownership concentration in Germany. Econ Policy 15:239-267

Edwards JSS, Weichenrieder AJ (2004) Ownership concentration and share valuation. Ger Econ Rev 5:143-171. doi:10.1111/j.1465-6485.2004.00100.x

Elston JA, Goldberg LG (2003) Executive compensation and agency costs in Germany. J Bank Finance 27:1391-1410. doi:10.1016/S0378-4266(02)00274-1

Fama EF, Jensen MC (1983) Separation of ownership and control. J Law Econ 26:301-325

Farrell KA, Hersch PL (2005) Additions to corporate boards: the effect of gender. J Corp Financ 11:85-106. doi:10.1016/j.jcorpfin.2003.12.001

Ferreira D (2010) Board diversity. In: Baker HK, Anderson R (eds) Corporate governance: a synthesis of theory, research, and practice. Wiley, Hoboken, pp 225-242

Forbes DP, Milliken FJ (1999) Cognition and corporate governance: understanding boards of directors as strategic decision-making groups. Acad Manag Rev 24:489-505

Franck E, Jungwirth C (1998) Vorurteile als Karrierebremse? Ein Versuch zur Erklärung des Glass Ceiling-Phänomens. Z Betriebswirtschaftliche Forschung 50:1083-1097

Franks J, Mayer C (2001) Ownership and control of German corporations. Rev Financ Stud 14: 943-977

Freedman DA (2006) On the so-called "Huber Sandwich Estimator" and "Robust Standard Errors." Am Statistician 60:299-302

Fryxell GE, Lerner LD (2009) Contrasting corporate profiles: women and minority representation in top management positions. J Bus Ethics 8:341-352

Goodstein J, Gautam K, Boeker W (1994) The effects of board size and diversity on strategic change. Strateg Manag J 15:241-250

GovernanceMetrics International (GMI) (2011) 2011 Women on Boards Report 
Gregoric A, Oxelheim L, Randoy T, Thomsen S (2010) How diverse can you get? Gender quotas and the diversity of nordic boards. Center for corporate Governance, Copenhagen Business School: Workingpaper

Harrigan KR (1981) Numbers and positions of women elected to corporate boards. Acad Manage J 24:619-625

Henrekson M, Stenkula M (2009) Why are there so few female top executives in egalitarian welfare states? Independent Rev 14:239-270

Hillman AJ, Shropshire C, Cannella AA (2007) Organizational predictors of women on corporate boards. Acad Manag J 50:941-952. doi:10.2307/20159898

Himmelberg CP, Hubbard GR, Palia D (1999) Understanding the determinants of managerial ownership and the link between ownership. J Finan Econ 53:353-384. doi:10.1016/S0304405X(99)00025-2

Hoetker G (2007) The use of logit and probit models in strategic management research: critical issues. Strateg Manag J 28:331-343. doi:10.1002/smj

Hollingshead AB, Fraidin SN (2003) Gender stereotypes and assumptions about expertise in transactive memory. J Exp Soc Psychol 39:355-363. doi:10.1016/S0022-1031(02)00549-8

Holst E, Wiemer A (2010) Zur Unterrepräsentanz von Frauen in Spitzengremien der WirtschaftUrsachen und Handlungsansätze. Biol Cell 103:1-17. doi:10.1042/BC20100104

Ivanov VI, Xie F (2010) Value to start-up firms? Evidence from IPOs and acquisitions of VC-backed companies. Finan Manag 39:129-152

Jehn KA, Northcraft GB, Neale MA (1999) Why differences make a difference: a field study of diversity, conflict, and performance in workgroups. Adm Sci Q 44:741-763. doi:10.2307/2667054

Jensen MC (1986) Agency cost of free cash flow, corporate finance, and takeovers. Am Econ Assoc 76:323-329. doi:10.2139/ssrn.99580

Jensen MC (1993) The modern industrial revolution, exit, and the failure of internal control systems. J Financ 48:831-880. doi:10.2307/2329018

Jensen MC, Meckling WH (1976) Theory of the firm: managerial behavior, agency costs and ownership structure. J Finan Econ 3:305-360

Kalev A, Dobbin F, Kelly E (2006) Best practices or best guesses? Assessing the efficacy of corporate affirmative action and diversity policies. Am Sociol Rev 71:589-617

Kilduff M, Angelmar R, Mehra A (2000) Top management-team diversity and firm performance: examining the role of cognitions. Organ Sci 11:21-34

Kim H, Kim H, Lee PM (2008) Ownership structure and the relationship between financial slack and r\&d investments: evidence from Korean firms. Organ Sci 19:404-418. doi: $10.1287 /$ orsc. 1080.0360

Krell G (2008) Programme und Maßnahmen zur Realisierung von Chancengleichheit in deutschen Großunternehmen von Mitte der 1990er Jahre bis 2006-Befragungen der Mitglieder des "Forum Frauen in der Wirtschaft". Chancengleichheit durch Personalpolitik -Gleichstellung von Frauen und Männern in Unternehmen und Verwaltungen. Rechtliche RegelungenProblemanalysen-Lösungen

Kronborg D, Thomsen S (2009) Foreign ownership and long-term survival. Strateg Manag J 30:207219. doi: $10.1002 / \mathrm{smj}$

La Porta R, Lopez-de-Silanes F, Shleifer A, Vishny RW (2000) Agency problems and dividend policies around the world. J Financ 55:1-33. doi:10.1111/0022-1082.00199

Lederle S (2007) Die Einfuehrung von Diversity Management in deutschen Organisationen-Eine neoinstitutionalistische Perspektive. Z Personalforschung 21:22-41

Leuz C, Lins KV, Warnock FE (2009) Do foreigners invest less in poorly governed firms? Rev Financ Stud 22:3245-3285. doi:10.1093/rfs/hhn089

Lynall MD, Golden BR, Hillman AJ (2003) Board composition from adolescence to maturity: a multitheoretic view. Acad Manag Rev 28:416-431. doi:10.2307/30040730 
McPherson M, Smith-Lovin L (1987) Homophily in voluntary organizations: status distance and the composition of face-to-face groups. Am Sociol Rev 52:370-379

McPherson M, Smith-Lovin L, Cook JM (2001) Birds of a feather: homophily in social networks. Annual Rev Sociol 27:415-444. doi:10.1146/annurev.soc.27.1.415

Morck R, Shleifer A, Vishny RW (1988) Management ownership and market valuation: an empirical analysis. J Finan Econ 20:293-315

Noe RA (1988) Women and mentoring: a review and research agenda. Acad Manag Rev 13:65-78

Oehmichen J (2010) Frauenquoten in Deutschland?-Wer Symptome lindert adressiert nur selten die Grundursache des Problems. ifo-Schnelldienst 63:10-12

Pearce JL, Xu QJ (2010) Rating performance or contesting status: evidence against the homophily explanation for supervisor demographic skew in performance ratings. Organ Sci (forthcoming). doi:10.1287/orsc. 1100.0585

Pelled LH (1996) Demographic diversity, conflict, and work group outcomes: an intervening process theory. Organ Sci 7:615-631

Randel AE (2002) Identity salience: a moderator of the relationship between group gender composition and work group conflict. J Organ Behav 23:749-766. doi:10.1002/job.163

Rapp MS, Wolff M (2010) Determinanten der Vorstandsvergütung-Eine empirische Untersuchung der deutschen Prime-Standard-Unternehmen. Z Betriebswirtschaft 80:1075-1112

Renneboog L (2000) Ownership, managerial control and the governance of companies listed on the Brussels stock exchange. J Bank Financ 24:1959-1995

Sealy R, Singh V, Vinnicombe S (2007) The Female FTSE Report 2007. Cranfield University

Shleifer A, Vishny RW (1997) A survey of corporate governance. J Financ 52:737-783. doi: $10.2307 / 2329497$

Siegelman L, Zeng L (1999) Analyzing censored and sample-selected data with tobit and heckit models. Polit Anal 8:167-182

Simons T, Pelled LH, Smith KA (1999) Making use of difference: diversity, debate, and decision comprehensiveness in top management teams. A Manag J 42:662-673

Simpson A, Smith T, Kvam A (2008) Should capital be socially responsible? Yale Q4 43-53

Sraer D, Thesmar D (2007) Performance and behavior of family firms: evidence from the french stock market. J Eur Econ Assoc 5:709-751. doi:10.1162/JEEA.2007.5.4.709

Straub C (2007) A comparative analysis of the use of work-life balance practices in Europe: do practices enhance females' career advancement? Women Manag Rev 22:289-304. doi: $10.1108 / 09649420710754246$

Süß S (2008) Diversity-Management auf dem Vormarsch. Eine empirische Analyse der deutschen Unternehmenspraxis. $Z$ betriebswirtschaftliche Forsch 60:406-430.

Terjesen S, Singh V (2008) Female presence on corporate boards: a multi-country study of environmental context. J Bus Ethics 83:55-63. doi:.1007/s10551-007-9656-1

Tharenou P (2008) Disruptive decisions to leave home: gender and family differences in expatriation choices. Organ Behav Hum Decis Process 105:183-200. doi:10.1016/j.obhdp.2007.08.004

Thomsen S, Pedersen T (2000) Ownership structure and economic performance in the largest European companies. Strateg Manag J 21:689-705.

Tsui AS, Egan TD, O’Reilly CA (1992) Being different: relational demography and organizational attachment. Adm Sci Q 37:549-579. doi:10.2307/2393472

Tuggle CS, Schnatterly K, Johnson RA (2010) Attention patterns in the boardroom: how board composition and processes affect discussion of entrepreneurial issues. Acad Manag J 53:550 571

Weber-Rey D (2009) Änderungen des Deutschen Corporate Governance Kodex 2009. Z Wirtsch Bankenrecht-Wertpapiermitteilungen 63:2255-2264

Westphal JD, Milton LP (2000) How experience and network ties affect the influence of demographic minorities on corporate boards. Adm Sci Q 45:366-398. doi:10.2307/2667075 